\title{
Menimbang Spiritualitas dan Seksualitas: Simbolik Efisiensi dalam Praktik Pesugihan Kembang Sore di Tulungagung
}

\author{
Nadya Afdholy ${ }^{\mathrm{a}, 1^{*}}$, Ghanesya Hari Murtib,2 \\ a Universitas Negeri Surabaya, Jl. Lidah Wetan, Lakarsantri, Surabaya, Indonesia, 60213 \\ b Politeknik Negeri Jember, Jl. Mastrip No. 64, Sumbersari, Jember, Indonesia, 68101 \\ ${ }^{1}$ nadyaafdholy@yahoo.com; ${ }^{2}$ ghanesya@polije.ac.id \\ * Corresponding Author
}

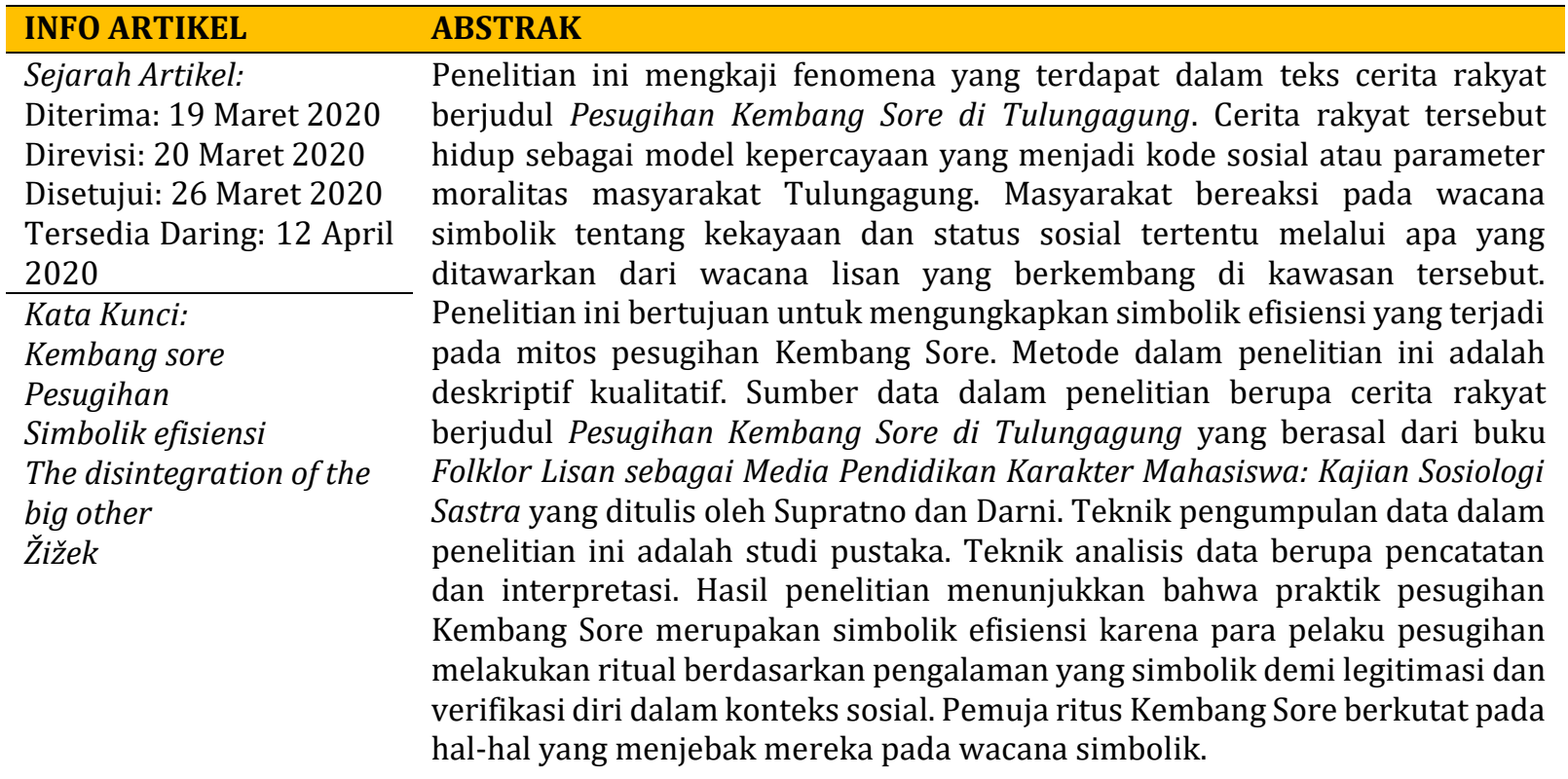

\begin{tabular}{l}
\hline Keywords: \\
Kembang Sore \\
Heretic ritual \\
Symbolic efficiency \\
The disintegration of the \\
big other \\
Žižek
\end{tabular}

ABSTRACT

This study examines the phenomena contained in the text of the folklore entitled Pesugihan Kembang Sore di Tulungagung. This folklore lives as a model of trust which becomes a social code or morality parameter of Tulungagung society. Society reacts to symbolic discourse about wealth and certain social status through what is offered from an oral discourse that develops in the region. This study aims to reveal the symbolic efficiency that occurs in the myth of the Kembang Sore heretic ritual. The method in this research is descriptive qualitative. The data source in the research was in the form of folklore entitled Pesugihan Kembang Sore di Tulungagung obtained from a book Folklor Lisan sebagai Media Pendidikan Karakter Mahasiswa: Kajian Sosiologi Sastra written by Supratno and Darni. Data collection techniques in this research are literature study. Data analysis techniques such as recording and interpretation. The results showed that the practice of Kembang Sore heretic ritual was symbolic efficiency because the heretic ritual practitioners performed rituals based on symbolic experience for legitimacy and self-verification in social contexts. Devotees of Kembang Sore rites dwell on things that trap them in symbolic discourse. 
How to Cite: Afdholy, N., \& Murti, G. H. (2020). Menimbang Spiritualitas dan Seksualitas: Simbolik Efisiensi dalam Praktik Pesugihan Kembang Sore di Tulungagung. JURNAL SATWIKA, 4 (1), 34-42 doi: https://doi/org/10.22219/SATWIKA.Vol4.No1.34-42

\section{Pendahuluan}

Pesugihan Kembang Sore adalah wacana lisan yang berkembang di masyarakat Tulungagung. Selama ini cerita rakyat yang berkembang di Tulungagung hanya dilihat secara dangkal (Asiyah, 2017). Masyarakat melihat cerita rakyat sebatas cerita dari nenek moyang yang diwariskan pada keturunanketurunannya. Cerita rakyat merupakan kolektif multikultural yang diwariskan secara tradisional (Mahardika, 2019). Wacana lisan yang berkembang di Tulungagung sejauh ini belum banyak dieksplorasi. Orang cenderung mengabaikan fungsi cerita rakyat dan menganggapnya sebatas mitos yang tidak memiliki nilai dan fungsi, padahal cerita rakyat yang hidup melalui tradisi lisan menyimpan paradoks karena membuat masyarakat terjebak tanpa menelusuri makna di baliknya.

Menurut Mashuri (2018), wacana lisan merupakan landasan kesadaran diri dan otonomi sebuah suku ketika berhubungan dengan dunia luar, baik verbal maupun nonverbal. Pengalaman non-verbal menceritakan realitas yang tidak terbahasakan dan tidak ada di dunia sebagai pengalaman yang riil. Bahasa membuat manusia saling berinteraksi dan mirroring di wilayah imajiner. Manusia akan meletakkan diri pada simbolik tertentu. Simbolik tidaklah tunggal, tetapi bermacammacam dan berubah secara terus menerus. Simbolik selalu berada dalam wilayah yang dinamis, sehingga manusia tidak lagi berpikir pada yang Big Other.

Konteks berkembanganya mitos pesugihan Kembang Sore di Tulungagung merujuk pada tokoh Roro Kembang Sore yang dituahkan. Model tokoh yang dituahkan seperti Roro Kembang Sore lekat dengan tradisi kelisanan yang kuat di masyarakat. Riantin mengatakan bahwa Roro Kembang
Sore adalah sosok yang diceritakan memiliki jiwa nasionalis yang tinggi karena membela tanah kelahirannya (Riantin, 2020). Dengan kata lain, Roro Kembang Sore yang secara penarasian punya karakter tokoh yang kuat melekat sebagai imajinasi sosial hingga saat ini. Tentu dengan penafsiran yang kontekstual sesuai dengan tradisi masyarakat.

Penelitian terdahulu yang terkait dengan mitos Pesugihan Kembang Sore sebagai berikut. Pertama, penelitian yang dilakukan oleh Desianasari (2016) Makna Sosial Ritual Pesugihan bagi Peziarah Makam Roro Kembang Sore Gunung Bolo Tulungagung (Studi Deskriptif Mengenai Makna Sosial Ritual Pesugihan bagi Para Peziarah Makam Roro Kembang Sore Gunug Bolo Tulungagung) menganalisis makna sosial ritual pesugihan bagi peziarah makam Roro Kembang Sore Gunung Bolo Tulungagung. Hasil penelitian menunjukkan bahwa pengunjuung memaknai ritual tersebut sebagai jalan penghubung, permohonan di depan sesaji, permintaan, ziarah, doa, sesaji, dan penyampaian keinginan di depan sesaji.

Kedua, Kurniawan (2016) berjudul Asmarangkara: Sebuah Pertunjukan Teater Masa Kini Berbasis Tradisi menghasilkan sebuah karya pementasan teater masa kini berbasis tradisi Asmarangka yang berisi kisah cinta Lumbu Peteng dengan Kembang Sore. Pementasan Asmarangka sebagai teater masa kini berbasis tradisi diharapkan dapat menjadi tatanan, tuntunan, dan tontonan bagi khalayak masyarakat.

Ketiga, Rosidah (2018) berjudul Folklor Lisan Kota Tulungagung: Balada Asmara Nyi Roro Kembangsore memaparkan sejarah profil kota Tulungagung dan relevansinya dengan balada asmara Nyi Roro Kembangsore dalam Babad Tulungagung. 
Hasil penelitian menunjukkan sejarah profil Tulungagung dan proses perkembangannya yang memiliki keterkaitan dengan namanama daerah di Tulungagung.

Berdasarkan pengamatan dari penelitian yang terkait mitos Kembang Sore, belum ditemukan penelitian mengenai simbolik efisiensi dalam mitos Pesugihan Kembang Sore di Tulungagung. Penelitian sastra lisan selama ini bersifat deskripsi atau memperjelas pernyataan audiensi yang melihat tradisi lisan sebagai dasaran moral pembentuk masyarakat, pedoman atau teladan, namun belum membidik secara riil tentang bagaimana praktik tersebut secara konkrit terjadi dalam masyarakat. Oleh karena itu, penelitian ini bertujuan untuk mengungkapkan simbolik efisiensi yang terjadi pada mitos Pesugihan Kembang Sore.

Konsep simbolik efisiensi yang digagas oleh Žižek digunakan untuk menerangkan fenomena teks cerita rakyat yang berjudul Pesugihan Kembang Sore di Tulungagung dengan pemaknaan untuk melegitimasi diri bahwa pelaku ritual Pesugihan Kembang Sore adalah bagian dari masyarakat. Selain itu dapat menambah motivasi diri bahwa apapun yang dilakukan setelahnya adalah sebuah kebenaran yang terlegitimasi. Simbolik efisiensi mengacu pada cara bagaimana fakta yang menjadi kenyataan itu tidak cukup bagi manusia yang hanya ingin mengetahuinya, tetapi manusia butuh mengetahui bahwa fakta tersebut juga diketahui oleh Big Other, yang dalam hal ini disebut sebagai verifikasi. Harapannya ada pengakuan karena sudah divalidasi oleh Big Other.

Dalam mitos Pesugihan Kembang Sore di Tulungagung tidak mungkin Big Other memverifikasikan diri. Big Other memberikan personalitas yang tidak terpusat karena Big Other dalam hal ini menciptakan subjek-subjek yang bertentangan. Big Other tidak memberikan pernyataan tunggal, tidak ada satu tafsir yang mutlak, tetapi hanya sebatas cerita-cerita. Akhirnya, manusia berdebat tentang tafsir dan muncullah contemporary subject karena mereka berada dalam dunia simbolik (Myers, 2003). Dengan kata lain, Big Other memberikan identitas ke berbagai macam personalitas yang tidak terpusat bagi subjek-subjek kontemporer. Manusia bisa saja mempunyai pandangan yang berbeda terhadap sesuatu. Selalu ada hierarki yang melahirkan perdebatan. Personalitas-personalitas tersebut tidak dapat diklaim sebagai status yang equal dalam dunia simbolik untuk penentuan posisi.

Terdapat urutan berpikir sebagai dasar yang memang ada dan dapat dibuktikan secara riil dalam sejarah, bukan hanya sebuah abstraksi. Aristotle mengumpamakan manusia seperti motor, ada motor yang bergerak dan ada yang tidak bergerak. Manusia selalu bergerak pada intelektual yang aktif sebagai intelektual pasif (Jacquette, 2019). Manusia bereaksi pada apa yang ditampilkan, bukan karena apa yang tercipta. Manusia tidak menciptakan realitas, tetapi realitas terhampar dengan sendirinya. Pendapat tersebut ditolak oleh orang postmodern. Bagi orang postmodern, manusia juga aktif menciptakan realitas dan struktur sosial.

Berbeda dengan persepsi Lacan. Bagi Lacan, manusia adalah simbolik efisiensi dari yang the Big Other (Winlow, 2019). Manusia mulai lepas dan lupa pada yang esensial dan sibuk bereaksi pada yang aksesori atau yang disebut oleh Žižek sebagai kesadaran palsu. Žižek menjelaskan bahwa terdapat inisialinisial simbolik dan berbagai pertentangan wacana yang terlibat dalam dimensi sosiokultural dengan harapan akan ada masyarakat yang equal/setara, tanpa konflik atau yang disebut dengan istilah masyarakat utopia. Lacan mengatakan simbolik adalah fana, yang asli adalah Big Other. Demi kembali ke pengalaman yang riil tidak bisa terjebak pada yang simbolik (Flisfeder, 2019). Usaha Lacan sia-sia yang kemudian dikonsep ulang oleh Žižek sebagai the Disintegration of the Big Other.

Konsep Big Other atau Big $O$ pada dasarnya adalah konsep dari Lacan, maka dari itu Žižek disebut Lacanian. Big $O$ bagi Lacan membentuk objektivitas sosial (Hook, 2008). $O$ dalam hal ini adalah Other, tetapi bukan other dalam artian minoritas atau 
Liyan karena $O$ dalam hal ini menggunakan $O$ besar, bukan $o$ kecil. Konsep tersebut bermula dari Aristotle. Aristotle beranggapan bahwa subjek manusia dibagi menjadi dua kategori yaitu intelektual pasif dan intelektual aktif (Zoga, 2018). Bagi Aristotle, manusia adalah intelektual pasif.

Manusia adalah yang serba tahu, tetapi pasif karena bereaksi pada sesuatu yang bukan dirinya. Manusia adalah intelektual pasif saat mencari informasi mengenai sesuatu yang mereka sukai, meniru, dan bahkan terpengaruh (Scaramuzzo, 2016). Manusia bekerja karena dukungan apa yang disodorkan oleh intelektual aktif, yang dalam kajian Airstotle disebut sebagai Tuhan. Lacan memecah konsep Big Other dengan menyebutkan Other yang lain sebagai wacana simbolik (Myers, 2003). Oleh karena itu, manusia selalu bergerak sesuai apa yang dikehendaki oleh Big Other. Manusia bergerak dalam wilayah simbolik.

Big Other memecah wacana tersebut menjadi simbolik-simbolik. Berurutan dari Other, $O$ yang besar, lalu terbagi-bagi menjadi wacana simbolik. Simbolik dalam hal ini diartikan sebagai realitas. Bagi Žižek, manusia telah terlepas dari pikiran-pikiran mengenai Other yang besar yang selama ini selalu diikuti secara terus menerus (Myers, 2003). Berdasarkan kutipan tersebut, manusia beranggapan bahwa Tuhan memecahkan pengetahuannya menjadi berbagai macam di dunia ini. Dengan menyukai atau mengidolakan sesuatu, maka secara tidak langsung manusia akan meniru semuanya yang simbolik. Manusia berada dalam simbolik karena manusia sebenarnya tidak pernah sampai kepada atau tidak mungkin menjadi yang diidolakan, sehingga yang ditiru adalah wacana simbolik.

Dunia ini ada karena medium perantara bahasa. Bahasa adalah simbol. Manusia dapat mendeskripsikan sesuatu melalui bahasa sampai pada kesepakatan tertentu. Manusia tidak lagi kembali ke Tuhan yang Big Other karena manusia telah terlepas dari wacana tunggal (Muzairi, 2017). Dalam artian tunggal yang diharapkan oleh Aristotle hingga Hegel, yaitu manusia sampai pada wacana Tuhan yang paling ultimum. Ilmu pengetahuan diharapkan sampai pada hal tersebut, tetapi manusia tidak pernah bisa sampai pada kategori tersebut (Myers, 2003). Hal tersebut dibuktikan oleh hadirnya satu manusia yang berusaha untuk sampai ke wacana yang ultimum (pemikiran tentang Tuhan), tetapi justru kehancuran-kehancuran yang diterima karena manusia tidak pernah sampai di sana.

Manusia terjebak pada wacana dan dimensi simbolik bahasa. Žižek berargumen bahwa manusia percaya pada model-model yang mereka lihat daripada apa yang diucapkan oleh Big Other, sehingga ketika ada wacana yang buruk mengenai hal tersebut, manusia dengan mudahnya tidak mempercayai apa yang terjadi (Myers, 2003). Setelah tahu bahwa Big Other yang terjebak pada wacana simbolik saat ini sudah tidak lagi diperlukan, tidak ada lagi yang Big Other. Manusia hanya percaya pada yang mereka lihat saja. Ketika semua manusia sudah tidak berupaya untuk sampai pada apa yang mereka idolakan, maka mereka terdisintegrasi. Tidak ada lagi intergasi, tetapi menjadi "disintegrasi". Berdasarkan hal tersebut maka hadirlah debat antar-teks.

Manusia tidak pernah sampai pada yang asli, tetapi mereka berdebat mengenai apa yang membuat mereka terjebak pada wacana simbolik, yaitu bahasa. Sifat bahasa adalah arbitrer. Manusia menyimpulkan masingmasing karena terjebak pada simboliknya masing-masing yang tidak selalu pada Big Other dan tidak pernah sampai pada yang utuh/esensi. Manusia hanya sampai pada tahap meniru dan terjebak pada simbolik, seperti yang diungkapkan Myers bahwa yang paling buruk dari postmodernitas adalah manusia tidak lagi berupaya untuk mencapai Big Other karena mereka sudah terintegrasi dan terjebak pada wacana simbolik (Myers, 2003). Manusia tidak lagi memikirkan esensi, tetapi yang paling penting adalah verifikasi dari orang lain. Manusia tidak lagi mencari yang Big Other, bahkan lebih menyukai yang aksesori (wacana simbolik). Manusia tidak lagi mencari yang substansial, tetapi mengejar yang lebih formal beserta 
aksesori-aksesorinya. Manusia tidak lagi merespon pada sesuatu yang asli, tetapi bereaksi pada yang simbolik yang membuatnya percaya diri. Seperti pada mitos Pesugihan Kembang Sore di Tulungagung, tidak penting apakah ritus berzina yang dilakukan oleh para pelaku pencari kesugihan tersebut melanggar hukum agama, tetapi yang lebih penting adalah legitimasi dan verifikasi. Pelaku pesugihan tidak bisa disalahkan karena tindakan yang dilakukan pun diamini oleh masyarakat sekitar. Praktik pesugihan Kembang Sore di Tulungagung tersebut terjadi karena manusia bereaksi pada yang akseseoris.

\section{Metode}

Metode yang digunakan dalam penelitian ini adalah deskriptif kualitatif guna mendeskripsikan, menganalisis dan menginterpretasikan data yang berhubungan dengan fenomena dalam teks yang diteliti. Sumber data yang digunakan dalam penelitian ini berupa kutipan-kutipan yang berasal dari cerita rakyat berjudul Pesugihan Kembang Sore di Tulungagung yang diperoleh dari buku Folklor Lisan sebagai Media Pendidikan Karakter Mahasiswa: Kajian Sosiologi Sastra yang ditulis oleh Supratno and Darni (2015) terbitan Unesa University Press yang terdiri dari 262 halaman. Cerita rakyat berjudul Pesugihan Kembang Sore di Tulungagung digunakan sebagai sumber data penelitian karena cerita rakyat tersebut hidup sebagai model kepercayaan yang menjadi kode sosial atau parameter moralitas masyarakat di Tulungagung yang fenomenanya tergambar di dalam teks.

Teknik pengumpulan data dalam penelitian ini dilakukan dengan studi pustaka yang sebelumnya diadakan seleksi data dengan close reading, menyimak, memilah, dan mencatat data-data yang berkaitan dengan fokus kajian, sehingga tidak semua data digunakan. Teknik analisis data dalam penelitian ini terdiri dari beberapa tahap, di antaranya pencatatan sebelum mencari makna dari keseluruhan teks untuk dideskripsikan dan dianalisis, kemudian interpretasi, dan menyimpulkan analisis terhadap keseluruhan data yang telah diperoleh.

\section{Hasil dan Pembahasan}

\subsection{Kepatuhan Spiritualitas Subjek yang Terbelah}

Spiritualitas dalam praktik pesugihan Kembang Sore merupakan aspek penting yang berkaitan dengan aktivitas pencarian akan transendensi yang dilakukan oleh individu sebagai makna dan tujuan hidupnya. Spiritualitas memberikan peluang bagi individu untuk memilih jalan spiritualitasnya daripada sekadar berkiblat pada norma yang berlaku. Orang yang berangkat ke Tulungagung berharap akan menjadi kaya, tetapi tidak semua melacak cerita tentang Roro Kembang Sore. Mitos pesugihan Kembang Sore di Tulungagung pada hakikatnya menarasikan kisah cinta tak sampai. Hal tersebut diperjelas dalam data berikut.

\footnotetext{
"Kisah cinta tak sampai antara Roro Kembangsore dan Pangeran Lumbupeteng, Adipati Kalang dan Roro Kembangsore, juga Joko Budheg dan Roro Kembangsore inilah yang menyebabkan makam Roro Kembangsore masih tetap dikeramatkan sampai saat ini." (Supratno \& Darni, 2015, p. 58).
}

Berdasarkan data tersebut dapat diketahui bahwa kisah cinta tak sampai yang terjadi pada Roro Kembang Sore dengan Pangeran Lumbupeteng, Adipati Kalang, dan Joko Budheg adalah sebab utama yang melegitimasi kekeramatan pada makam Roro Kembang Sore. Kendati demikian, makam tersebut masih ramai peziarah di malam Minggu hingga saat ini, seperti pada data berikut.

\footnotetext{
"Bila malam tiba, khususnya malam Minggu, lokasi di sekitar makam tersebut ramai dikunjungi para peziarah yang ingin mencari pesugihan." (Supratno \& Darni, 2015, pp. 58-59).
} 
Data tersebut menunjukkan bahwa peziarah yang datang adalah orang-orang yang memang mencari pesugihan. Para pezirah padat memenuhi makam Roro Kembang Sore, terutama di malam Minggu. Dalam hal ini spiritualitas memiliki efek yang independen (tidak hanya dalam hal religiusitas yang berkaitan dengan keyakinan) karena para pelaku pesugihan Kembang Sore berpartisipasi dalam praktik tersebut berdasar minat pribadi walaupun sifatnya irasional. Spiritualitas subjek yang terbelah dalam hal ini menunjuk para pelaku pesugihan yang di satu sisi ingin menjajal kekuasaan dengan ritus zina, tetapi di sisi lain patuh dengan menyembelih kambing sebagai simbol kepatuhan. Spiritualitas ditekankan dalam praktik pesugihan karena menjadi upaya pemberdayaan secara sosial demi mencapai kesejahteraan secara batiniah maupun secara emosional. Tidak peduli cara yang ditempuh demi meraih kekayaan tersebut dapat dilogika atau tidak. Mereka tetap berangkat ke pemakaman dan melakukan ritual meski tindakan tersebut nampak irasional.

\subsection{Zina sebagai Bagian dari Ritus}

Praktik pesugihan Kembang Sore identik dengan ritual zina. Zina dalam hal ini merupakan bagian dari ritus, yang bagi Žižek disebut sebagai aksesori. Orang yang melakukan ritus hanya membutuhkan sugesti lebih bahwa dengan melakukan ritus zina, pelaku akan mendapatkan energi lebih. Perkara tindakan berzina, pelaku tidak akan merasa bersalah karena hal tersebut merupakan bagian dari ritus. Ritus yang dilakukan oleh pelaku pesugihan di makam Roro Kembang Sore secara kasat mata terlihat irasional, seperti pada data berikut.

"Di bukit itu juga terdapat makam Roro Kembang Sore yang dipercaya memiliki tuah gaib yang bisa membantu para pemujanya untuk memperoleh kekayaan dengan cara irasional." (Supratno \& Darni, 2015, p. 54).

Secara gamblang, masyarakat akan menilai bahwa ritual yang irasional atau zina adalah kesalahan, tetapi ritual zina di Tulungagung terproteksi, tidak ada yang menghakimi, semua orang yang mencari kekayaan akan melakukan ritus tersebut. Tidak ada rasa berdosa karena hal tersebut adalah bagian dari syarat dan memang itu yang mereka cari, bahkan mereka melakukannya dengan bahagia. Ritus dilakukan demi diverifikasi bahwa setelah ini mereka yang melakukan ritus akan menjadi kaya raya. Akhirnya, wacana tersebut mengundang orang lain untuk memberikan jasa, yaitu jasa prostitusi, seperti pada data berikut.

"Uniknya, di antara para peziarah itu banyak pula perempuan penjaja seks. Dengan banyaknya Pekerja Seks Komersial (PSK) di Bukit Bolo maka terjadi perpaduan antara wisata seks, dan wisata spiritual." (Supratno \& Darni, 2015, p. 59).

Para perempuan penjaja tubuh datang dengan sendirinya tanpa diundang karena mereka tahu bahwa pasti ada yang membeli. Karena ada wacana Pesugihan Kembang Sore, maka ada perempuan-perempuan penjaja seks komersil. Wacana pesugihan menghendaki istilah berhubungan dengan non-pasangan. Mereka tidak takut berdosa karena yang dianggap dosa justru diverifikasi sebagai yang penting dalam ritus. Ritual zina adalah satu-satunya cara untuk diverifikasi. Dengan melakukan zina maka dia sudah menyelesaikan tugasnya.

Setelah melakukan zina, harapannya mendapat motivasi diri yang dinamakan proses verifikasi. Setelah melakukan semua ritual berarti orang tersebut akan terverifikasi otomatis dan merasa mantab bahwa dia akan mendapatkan kekayaan. Seksualitas dalam hal ini berarti relasi kekuasaan yang sifatnya transaksional.

\subsection{Menyembelih Kambing sebagai Syarat Akhir Verifikasi}

Ritual zina bukan akhir dari syarat untuk terverifikasi. Masih ada syarat lain yang harus dilakukan oleh pelaku pesugihan, yaitu 
menyembelih kambing, seperti pada data berikut.

"Jika yang diinginkan sudah tercapai maka pada hari Jum'at Pon pencari pesugihan lantas menyembelih kambing di makam Roro Kembang Sore." (Supratno \& Darni, 2015, p. 59)

Syarat menyembelih kambing dilakukan di makam Roro Kembang Sore dan harus pada hari tertentu, yaitu Jumat Pon. Penyembelihan kambing dapat diartikan sebagai bentuk upeti yang berujung pada kepatuhan. Hal tersebut merupakan sikap patuh feodalisme dan patron. Kepatuhan absolut pada Roro Kembang Sore dilakukan tanpa rasa ragu sedikit pun yang merujuk pada internalisasi kepatuhan dalam spiritualitas. Orang akan pergi ke Tulungagung untuk melakukan ritual yang merupakan bagian dari the Disintegration of the Big Other.

\subsection{Local Kingdom dalam Mitos Pesugihan Kembang Sore}

Jika dibandingkan dengan local wisdom, ada local kingdom dalam mitos Pesugihan Kembang Sore di Tulungagung. Selama ini masyarakat memahami hal tersebut sebagai kearifan lokal atau urban legend, tetapi hal yang terjadi justru mitos Pesugihan Kembang Sore melahirkan bibit baru, terdapat hierarki dalam hal tersebut. Wacana pesugihan dianggap sebagai wacana yang biasa karena didukung oleh masyarakat, seperti pada data berikut.

"Di bukit itu juga terdapat makam Roro Kembang Sore yang dipercaya memiliki tuah gaib yang bisa membantu para pemujanya untuk memperoleh kekayaan dengan cara irasional." (Supratno \& Darni, 2015, p. 54)

Data tersebut memaparkan bahwa masyarakat percaya pada mitos Pesugihan Kembang Sore di Tulungagung yang tidak dapat digugat, bahkan memiliki kekuatan yang tinggi. Semua yang mengatur adalah masyarakat sehingga supremasinya tinggi. Salah satu ritus untuk mendapatkan pesugihan adalah dengan cara berzina dengan yang bukan pasangannya.

\subsection{Simbolik Efisiensi dalam Praktik Pesugihan Kembang Sore}

Fenomena yang tergambar dalam teks cerita rakyat Pesugihan Kembang Sore di Tulungagung menggambarkan praktik Pesugihan Kembang Sore yang merupakan simbolik efisiensi. Secara gerak kebudayaan para pelaku melakukan ritual pesugihan berdasarkan pengalaman yang simbolik. Disebut efisien karena para pelaku melegitimasi seluruh tindakannya sebagai sesuatu yang natural dan normal. Pertentangan mengapa hal tersebut bisa terjadi dan tidak ada yang menghentikan ritual tersebut disebut sebagai simbolik efisiensi.

Selama ini masyarakat terjebak pada harapan untuk menjadi "kaya" setelah melakukan ritus, tetapi pemahaman penting sampai pada proses Big Other tidak pernah diulik, seperti pertanyaan bagaimana mitos pesugihan Kembang Sore di Tulungagung dapat memberikan kekayaan tidak pernah dicari tahu karena bagi masyarakat yang terpenting adalah simboliknya. Begitu simbolik ada dalam hal itu, maka wacana hadir di situ. Big Other membuat pelaku pesugihan ingin mencapai yang Big Other. Big Other dalam hal ini adalah kekayaan dari pesugihan. Manusia tidak pernah sampai pada Big Other, tetapi mereka terjebak pada simbolik, yaitu pesugihan. Pesugihan adalah simbolik. Pesugihan memberikan wacanawacana tertentu, seperti ritual zina dan menyembelih kambing. Dengan melakukan yang simbolik, mereka merasa diverifikasi atau diiyakan oleh Big Other.

Seusai melakukan ritus panjang mereka yakin akan menjadi kaya. Hal tersebut adalah proses untuk mendapatkan verifikasi yang menurut Žižek disebut sebagai simbolik efisiensi. Žižek ingin mengefisienkan simbolik supaya mendapatkan legitimasi atas 
tindakannya. Pemaknaannya adalah sepulang dari Tulungagung, mereka akan mendapatkan motivasi baru bahwa apapun yang mereka lakukan setelah melakukan ritus dengan benar, maka mereka akan terlegitimasi sebagai pemeroleh kekayaan berikutnya.

Simbolik efisiensi hanya bekerja jika pelaku diakui dan dituntut secara sosial. Menjadi orang kaya adalah tuntutan secara sosial. Kembang sore menawarkan hal tersebut. Simbolik dalam hal ini memiliki unsur feodal dan patronisasi yang kuat, oleh karena itu makam Roro Kembang Sore dianggap sebagai leluhur yang terpandang. Semua wacana simbolik itu bersitegang, tetapi muaranya ada pada uang, selain uang hanyalah pelengkap. Hal tersebut merupakan alasan ritus yang dilakukan betapa buruk dalam pandangan, tetapi sulit diberantas karena secara norma kultural dilegitimasi sebagai simbolik efisiensi.

Praktik pesugihan sulit dihilangkan kendati miring diperbincangkan karena cerita Roro Kembang Sore sesuai dengan impian simbolik masyarakat. Tentang kekuasaan, harta, dan prostitusi adalah sebuah imajinasi yang merupakan ciri saat kekuasaan diraih. Seks, zina, dan prostitusi dalam hal ini adalah cara mengintip impian, kekuasaan, dan harta.

\section{Kesimpulan}

Praktik Pesugihan Kembang Sore di Tulungagung adalah sebuah simbolik efisiensi karena para pelaku melakukan ritual berdasarkan pengalaman yang simbolik. Manusia tidak lagi merespon yang asli, tetapi justru bereaksi pada yang simbolik, yakni pesugihan demi legitimasi dan verifikasi. Ketika manusia sudah tidak berusaha untuk sampai pada Big Other, maka mereka terdisintegrasi, sehingga lahirlah debat antar teks yang secara implisit dapat diartikan bahwa manusia tidak pernah sampai pada yang asli, mereka hanya berdebat tentang hal- hal yang membuat mereka terjebak pada wacana simbolik.

Permasalahan spiritualitas dan seksualitas adalah bentuk substitusi dari gagalnya masalah ekonomi. Proyek dari rasionalitas di Indonesia berada pada masalah ekonomi. Apabila masalah ekonomi tidak selesai dan tidak dapat ditempuh secara rasional, maka tiba di keputusan-keputusan yang irasional yaitu praktik pesugihan dan prostitusi. Praktik-praktik tersebut dapat mereda apabila massalah ekonomi terselesaikan. "Klenik" di Indonesia tidak berakhir karena masalah ekonomi pun belum selesai. Masalah ekonomi belum terselesaikan karena akses untuk meraih ekonomi secara rasional tidak ada. Ketika semua jalan buntu, maka Kembang Sore tetap hidup dengan harapan mendapat jaminan ekonomi melalui praktik pesugihan.

\section{Daftar Pustaka}

Asiyah, N. (2017). Legenda di Tulungagung (Kajian Strukturalisme Claude Levi Strauss). BAPALA, 4(1), 1-11. Retrieved from https://jurnalmahasiswa.unesa.ac.id/i ndex.php/bapala/article/view/19110

Desianasari, d. (2016). Makna Sosial Ritual Pesugihan bagi Peziarah Makam Roro Kembang Sore Gunung Bolo Tulungagung (Studi Deskriptif Mengenai Makna Sosial Ritual Pesugihan bagi Para Peziarah Makam Roro Kembang Sore Gunug Bolo Tulungagung). Komunitas, 5(2), 115. Retrieved from http://journal.unair.ac.id/downloadfullpapers-kmntsac7b2efc8dfull.pdf

Flisfeder, M. (2019). Postmodern Marxism Today: Jameson, Žižek, and the Demise of Symbolic Efficiency. International Journal of Žižek Studies, 13(1), 22-56. Retrieved from http://zizekstudies.org/index.php/IJZ $\underline{\text { S/article/view/1105 }}$

Hook, D. (2008). Six Moments in Lacan. London: Routledge. 
Jacquette, D. (2019). Brentano on Aristotle's Psychology of the Active Intellect. In G. Hartung, C. G. King, \& C. Rapp (Eds.), Aristotelian Studies in 19th Century Philosophy (pp. 149-178). Boston: Deutsche Nationalbibliothek.

Kurniawan, T. U. (2016). Asmarangkara: Sebuah Pertunjukan Teater Masa Kini Berbasis Tradisi. (Master Tesis), Institut Seni Yogyakarta, Yogyakarta.

Mahardika, A. D. (2019). Pangaribawane Legendha Pasarean Syekh Basarudin Tumrap Tradhisi Nyadran ing Dhusun Srigading Desa Bolorejo Kecamatan Kauman Kabupaten Tulungagung (Tintingan Folklor). BARADHA, 6(1), 1-11. Retrieved from

http://jurnalmahasiswa.unesa.ac.id/in dex.php/baradha/article/view/26932/ 24648

Mashuri, M. (2018). Cerita-cerita Pesugihan di Jawa: Pola Kekerabatan Sastra dan Paradoks Teks-Konteks. Paper presented at the Kongres Bahasa Indonesia Jakarta. http://repositori.kemdikbud.go.id/10 $\underline{112 /}$

Muzairi, M. (2017). Diskursus Mengenai Tuhan di Dalam dan di Luar Metafisika (God Is Being and God Without Being). Refleksi, 17(1), 1-21. Retrieved from http://ejournal.uinsuka.ac.id/ushuluddin/ref/article/dow $\underline{\text { nload/1869/1420 }}$

Myers, T. (2003). Slavoj Žižek. London: Routledge.

Riantin, R. (2020). Filosofi Karakter Nasionalis dalam Babad Tulungagung. NOSI, 8(1), 1-7. Retrieved from http://riset.unisma.ac.id/index.php/N $\underline{\text { OSI/article/view/5813/4776 }}$
Rosidah, N. (2018). Folklor Lisan Kota Tulungagung: Balada Asmara Nyi Roro Kembangsore. (Sarjana Skripsi), Institut Agama Islam Negeri Tulungagung, Tulungagung. Retrieved from http://repo.iaintulungagung.ac.id/id/eprint/9483

Scaramuzzo, G. (2016). Aristotle's homo mimeticus as an Educational Paradigm for Human Coexistence. Journal of Philosophy of Education, 246-260.

Supratno, H., \& Darni, D. (2015). Folklor Lisan sebagai Media Pendidikan Karakter Mahasiswa: Kajian Sosiologi Sastra. Surabaya: Unesa University Press.

Winlow, S. (2019). What Lies Beneath? Some Notes on Ultra-realism, and the Intellectual Foundations of the 'Deviant Leisure' Perspective. In T. Raymen \& O. Smith (Eds.), Palgrave Studies in Crime, Media and Culture (pp. 45-65). Cham: Palgrave Macmillan.

Zoga, C. (2018). The Aristotelian Active Intellect on the Basis of the Actualitypotentiality Dichotomy. Paper presented at the Proceedings of the XXIII World Congress of Philosophy, Greece. 